\title{
Placing Jerusalemites in the History of Jerusalem: The Ottoman Census (sicil-i nüfüs) as a Historical Source
}

\author{
Michelle U. Campos
}

Over a decade ago, the distinguished Palestinian historian Rashid Khalidi published "A Research Agenda for Writing the History of Jerusalem," in which he identified a number of notable problems in the then-extant historiography of the city: historical unevenness, an imbalanced emphasis on some subjects and communities, and significant thematic gaps in intellectual, religious, legal, urban, and demographic history. ${ }^{1}$ Since then, there has been a wave of important works on Ottoman Jerusalem addressing some of Khalidi's desiderata. However, there is still much work that can and should be done. ${ }^{2}$ One of the

1 Rashid I. Khalidi, "A Research Agenda for Writing the History of Jerusalem," in Pilgrims, Lepers, and Stuffed Cabbage: Essays on Jerusalem's Cultural History, ed. Issam Nassar and Salim Tamari (Jerusalem: Institute of Jerusalem Studies, 2005).

2 For recent works on the Ottoman period alone, see Bedross Der Matossian, Shattered Dreams of Revolution: From Liberty to Violence in the Late Ottoman Empire (Stanford: Stanford University Press, 2014); Vincent Lemire, Jérusalem 19oo: La ville sainte à l'âge des possibles (Paris: Armand Colin, 2013); Abigail Jacobson, From Empire to Empire: Jerusalem between Ottoman and British Rule (Syracuse: Syracuse University Press, 2011); Michelle U. Campos, Ottoman Brothers: Muslims, Christians, and Jews in Early Twentieth Century Palestine (Stanford: Stanford University Press, 2011); Johann Büssow, Hamidian Palestine: Politics and Society in the District of Jerusalem, 1872-1908 (Leiden: Brill, 2011); Salim Tamari, Year of the Locust: A Soldier's Diary and the Erasure of Palestine's Ottoman Past (Berkeley: University of California Press, 2011); Musa Sroor, Fondations pieuses en mouvement de la transformation du statut de propriété des biens waqfs à Jérusalem (1858-1917) (Beirut; Damascus: Institut français du Proche-Orient (Ifpo); Aix-en-Provence: Institut de recherches et d'études sur le monde arabe et musulman (IRемAм), 2010); Vincent Lemire, La soif de Jérusalem: essai d'hydrohistoire (1840-1948) (Paris: Publications de la Sorbonne, 2010); Roberto Mazza, Jerusalem from the Ottomans to the British (London: I. B. Tauris, 2009); Yair Wallach, "Readings in Conflict: Public Texts in Modern Jerusalem, 1858-1958" (PhD diss., Birkbeck College, University of London, 2008); Yasemin Avcı, Değişim sürecinde bir Osmanlı Kenti: Kudüs (1890-1914) [An Ottoman city in the period of transformation: Jerusalem, 1890-1914] (Ankara: Phoenix, 2004); Salim Tamari and Issam Nassar, eds., Al-Quds al-Uthmaniyya fi alMudhakkirat al-Jawhariyya: al-Kitab al-Awwal min Mudhakkirat al-Musiqi Wasif Jawhariyya,

(C) MICHELlE U. CAMPOS, 2018 | DOI:10.1163/9789004375741_004

This is an open access chapter distributed under the terms of the prevailing CC-BY-NC-ND License at the time of publication. 
weakest spots in the enormous literature on Jerusalem is the field of social history, demonstrated by the general absence of ordinary Jerusalemites in many of the city's written histories.

Due to the kinds of sources preserved and typically accessed, as well as the past focus of scholarly and public interest, a great deal is known about certain elites and segments of the Jewish communities in Jerusalem, while very little is known about the rest of the urban population. In an effort to reinsert Jerusalemites onto their urban landscape (in their houses, in the markets, and on the streets), my current project turns to the Ottoman-era census (nüfüs) records from Jerusalem. This incomparable historical source offers startling insights into Jerusalem's history on its own, but will also undoubtedly serve as a necessary building block for future social historical work. Most importantly, the Jerusalem census records allow us to painstakingly reconstitute snapshots of Jerusalem's permanent population at two particular moments in time. We gain unparalleled (though partial) insights onto social structure, economic history, family life, and urban morphology. Furthermore, the census illuminates not only the rich tapestry of urban residents, but also sheds light on relations between the city and surrounding countryside, and between Jerusalem and other Palestinian and Ottoman towns and cities, presenting Jerusalem as a part of a global migration network. Moreover, as the most comprehensive census records currently available from any Ottoman city, the Jerusalem census holds great value for comparative Ottoman urban and social history.

Importantly, the census also allows us to write a "connected" social history of the city; helping to bridge the religious, ethnic, class, and nationalist chasms which have characterized too much of the historiography until recent years. ${ }^{3}$ Many of these newer works referenced earlier offer their own distinct

1904-1917 [Ottoman Jerusalem in the Jawhariyyeh memoirs: the first book from the memoirs of the musician Wasif Jawhariyya, 1904-1917] vol. 1 (Beirut: Institute for Palestine Studies, 2003); Akram Musallam, ed., Yawmiyat Khalil al-Sakakini [Diaries of Khalil Sakakini], vol. 1 (Ramallah: Khalil Sakakini Culture Centre; Institute of Jerusalem Studies, 2003).

3 Such a connected history would not only expand on the postcolonial notion of "relational history" that emerged in the 1990s in the Israeli-Palestinian context among "critical sociologists" and "revisionist historians" such as Baruch Kimmerling, Zachary Lockman and Gershon Shafir, but would also take up the broader theoretical challenge to static visions of communalism, "groupism," and ethnic identities. On relational history in the Israeli-Palestinian context, see especially Baruch Kimmerling, "Be'ayot Konseptu’aliyot ba-Historyografya shel 'Erets 'Ahat u-Shne 'Amim" [Conceptual problems in the historiography of one land with two peoples], in Eretz ahat u-shne 'amim [One land, two peoples], ed. Danny Ya'akobi (Jerusalem: Magnes Press, 1999); Zachary Lockman, "Railway Workers and Relational History: Arabs and Jews in British-Ruled Palestine," Comparative Studies in Society and History 35, no. 3 (1993); 
visions of Jerusalem as a connected city, visions theorized to varying degrees and bridging languages, communities, and historiographies in their coverage of different thematic issues. Furthermore, some of these works have even explored Jerusalemites' visions and practices of a shared urban citizenship as a common thread that bound them. ${ }^{4}$ What is needed still, however, is a better understanding of the demographic contours of that urban citizenry. In this chapter I discuss the nüfüs as a source, as well as some of the methodological challenges and opportunities involved in working with it.

\section{The Census: Background, Context and Historiography}

First, a few historical comments about the emergence of the Ottoman census and historiographic observations about the state of Ottoman and Palestinian nüfüs studies are in order. Although the Ottomans kept extensive tax registers (tahrir defterleri) in various parts of the empire from the fifteenth through seventeenth centuries, the first major empire-wide modern population censuses did not take place until the middle of the nineteenth century. ${ }^{5}$ After a series

Gershon Shafir, Land, Labor and the Origins of the Israeli-Palestinian Conflict, 1882-1914 (Berkeley: University of California Press, 1996); Zachary Lockman, Comrades and Enemies: Arab and Jewish Workers in Palestine, 1906-1948 (Berkeley: University of California Press, 1996). For conceptual critiques of groupism and static views of ethnicity, see Rogers Brubaker, "Ethnicity without Groups," Archives européennes de sociologie 43, no. 2 (2002); Jimy M. Sanders, "Ethnic Boundaries and Identity in Plural Societies," Annual Review of Sociology 28 (2002); Fredrik Barth, "Enduring and Emerging Issues in the Analysis of Ethnicity," in The Anthropology of Ethnicity: Beyond "Ethnic Groups and Boundaries," ed. Hans Vermeulen and Cora Govers (The Hague: Het Spinhuis, 1994).

4 See especially Yasemin Avcı, Vincent Lemire and Falestin Nä̈li, "Publishing Jerusalem's Ottoman Municipal Archives (1892-1917): A Turning Point for the City's Historiography," Jerusalem Quarterly, no. 60 (2015); Campos, Ottoman Brothers; Jacobson, From Empire to Empire; Avcı, Değişim sürecinde bir Osmanlı Kenti.

5 For a historical geography of rural Palestine based on the sixteenth-century tax registers, see Wolf-Dieter Hütteroth and Kamal Abdulfattah, Historical Geography of Palestine, Transjordan and Southern Syria in the Late 16th Century (Erlangen: Erlanger Geographische Arbeiten, 1977). For a methodological discussion of the tahrïr defterleri, see Metin M. Coşgel, "Ottoman Tax Registers (Tahrir Defterleri)," Historical Methods 37, no. 2 (2004). Although there is record of a series of population recordings taking place from the 1830s-1870s, these served conscription purposes and as a result recorded men only. For a study drawing on these yoklama defterleri in the Black Sea region, see Justin McCarthy, "Age, Family, and Migration in Nineteenth-Century Black Sea Provinces of the Ottoman Empire," International Journal of Middle East Studies 10, no. 3 (1979). Schölch analyzed Ottoman records from 1849 and 1871 
of preliminary starts (chiefly consisting of conscription and male population registers) and new imperatives due to a variety of concerns relating to taxation, conscription, non-Muslim communities, and bureaucratic reforms, the first sicil-i nüfūs nizāmnāmesi (population registry ordinance) was issued in 1881, and over the following decade a comprehensive census was conducted throughout the empire. ${ }^{6}$

The census was based on a household-level survey, aimed at documenting all men, women and children in residence. Ottoman subjects were recorded in separate notebooks divided according to millet (Ott. Turk. millet; Ar. milla/ millat); Muslims also were registered according to their urban neighborhood. Attempts were made to register foreign citizens and foreign institutions in separate notebooks as well, although in most of these cases, "foreigner" is taken to mean "nonlocal," as many of the individuals registered here hail from other towns in Palestine or the Ottoman Empire. In this first census, which I will refer to as the 1299 census $(1883-84),{ }^{7}$ the following fields were recorded on one page (from right to left) (fig. 1.1):

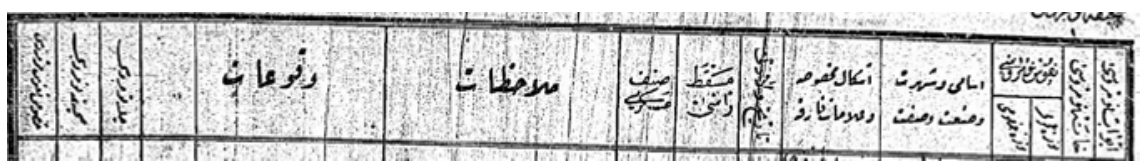

1-3 Ordinal fields (for household number, numbers of male members and female members)

4 Name/patronym/trade

$5 \quad$ Personal traits and distinguishing information

6 Date of birth

7 Place of residence

8 Army status

9 Notes

10 Events (life cycle)

FIGURE 1.1 Ottoman census header, 1299 [1883-84].

ISRAEL STATE ARCHIVES.

in Palestine. Alexander Schölch, "The Demographic Development of Palestine, 1850-1882," International Journal of Middle East Studies 17, no. 4 (1985).

6 For vital background, see Kemal Karpat, "Ottoman Population Records and the Census of 1881/82-1893," International Journal of Middle East Studies 9, no. 3 (1978); Stanford J. Shaw, "The Ottoman Census System and Population, 1831-1914," International Journal of Middle East Studies 9, no. 3 (1978).

7 This refers to the Ottoman administrative (fiscal $/ m \bar{a} / \bar{\imath}$ ) year when recording began. Since the $m a \bar{l} \bar{\imath}$ year begins in March and continues through the following February, this corresponds to $1883-84$. 
Newspapers, village, and neighborhood mukhtars, as well as millet leaders were charged with informing Ottoman subjects about the new regulations, procedures, and updates. In general, subjects were required to report to the local government offices (sarāy), where the nüfüs clerks held regular office hours, with identifying papers or witnesses and the requisite registration fee. In order to ensure compliance, the Ottoman government both incentivized participation and punished shirkers: census registration was a prerequisite for receiving the nüfüs tezkeresi, a vital government document necessary for land purchase, court appearances and travel documents, among other things. At the same time, subjects who failed to register were threatened with fines and imprisonment.

Compilation of the census stretched out over almost a decade and results were published in the local press as well as in imperial yearbooks (salnames). At its conclusion, however, serious criticisms were raised about census methodology and uneven compliance, prompting a revision of the census regulations in 1901, and a new empire-wide census launched shortly thereafter. ${ }^{8}$ Among the main changes between the first (1299/1883-84) and second (1321/1905-6) censuses were new procedures for ongoing registration of vital statistics in separate registers as well as updates in the original census books, the addition of new biographical data categories, and a more comprehensive attempt to record locational data. In these ways, the registration of Ottoman subjects became more thorough while, at the same time, the registration of "foreigners" seems to have dropped off, as many more non-Jerusalemites were incorporated into the regular notebooks.

The changes to the 1321 census included the addition of more data fields to create a standard two-page form (fig. 1.2):

8 I will refer to this as the $13^{21}\left(1905^{-6}\right)$ census, again referring to the māli year in which recording began. 


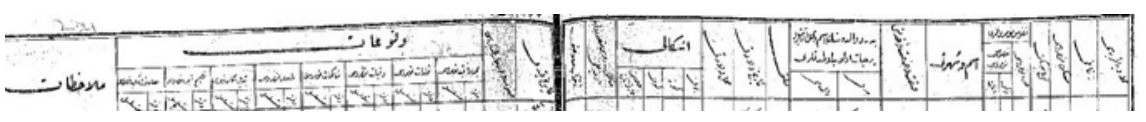

1-2 Locational data (maḥalle, zukāạ, house number)

3, 5 Ordinal fields

4 Building type

6 Name (including honorifics; other household members were prefaced by their relationship to the head of household)

7 Occupation/trade (languages known occasionally included)

8 Parents (father/mother fields separated; deceased parents marked as such)

$9 \quad$ Millet

10-11 Birth (year and city/village)

12 Physical traits (filled for men only)

13 Marital status (inconsistently filled)

14 Election status (rarely filled)

15 Date of registration

16 Military status (rarely filled)

17 Life cycle events (vuku'ät - inconsistently entered)

18 Notes (inconsistently entered, but could include information about life cycle events registered; subsequent relocations; at times court cases, army service or deferrals, elections status, etc.)

FIGURE 1.2 Ottoman census header, 1321 [1905-6].

ISRAEL STATE ARCHIVES.

Together, the two Ottoman censuses gathered a remarkable and unprecedented amount of information about millions of imperial subjects. Despite their unique and undeniable historical significance, however, there is relatively little scholarship based on Ottoman census records, perhaps due to the inaccessibility of most of the records themselves, the tedious nature of working with them, and the declining interest in quantitative social history since the $1970{ }^{9}{ }^{9}$ That said, there are several distinct trends and changes in the tiny field worthy of mention.

Much of the first generation of nüfüs scholarship dealt with calculating aggregates at the imperial and provincial levels. ${ }^{10}$ For these scholars, the emphasis was on measuring the accuracy of the census for the purpose of

9 For an albeit outdated introduction, see Daniel Panzac, La population de l'empire ottoman: cinquante ans (1941-1990) de publications et de recherches (Aix-en-Provence: Institut de recherches et d'études sur le monde arabe et musulman (IREMAM), 1993).

10 Kemal H. Karpat, Ottoman Population, 1830-1914: Demographic and Social Characteristics (Madison: University of Wisconsin Press, 1985); Justin McCarthy, Population History of the Middle East and the Balkans (Istanbul: Isis Press, 2002); McCarthy, The Population of Palestine: Population History and Statistics of the Late Ottoman Period and the Mandate (New York: Columbia University Press, 1990). 
providing a "scientific" demographic history of the empire or for combatting the demographic claims of former Ottoman minorities, or both. ${ }^{11}$ Among these scholars a consensus emerged that the 1321 census was far more comprehensive and reliable than the 1299 census, although in both cases there was an acknowledged slight-to-significant undercounting of nomads, rural residents, women and children, some ethno-religious groups in certain locales, and certain urban social classes. ${ }^{12}$

A second wave of nüfüs scholarship utilized the census on smaller provincial, city, or neighborhood scales, either in aggregate or through sampling, in order to discuss broader patterns of family, household, migration, demographics and urban history. The most prominent works in this vein have focused on Istanbul, but there are a few studies from other cities or provinces from which to draw comparisons. ${ }^{13}$ The extant scholarship on Palestine fits into this model

11 Servet Mutlu, "Late Ottoman Population and Its Ethnic Distribution," Turkish Journal of Population Studies 25 (2003). The Ottomans were not the only ones interested in their population figures; for their own reasons, European powers closely monitored Ottoman population results, and many additional and competing population estimates were given by European diplomats, travelers, missionaries, church officials, and in the specific case of Palestine, Zionist officials and settlers. However, for the most part, none of these other population counts were based on any discernible methodology close to the Ottoman census, and seem to be little more than the "guesstimate" impressions of one observer that were repeatedly cited until they assumed the status of consensus. This is clearest in the case of Palestine, where the population estimates of Arthur Ruppin, the World Zionist Organization official in Jaffa from 1908 onward, were adopted by the British Mandatory regime despite any method or justification. John Bernard Barron, Palestine: Report and General Abstracts of the Census of 1922 (Jerusalem: Greek Convent Press, 1923), 3. Karpat, Ottoman Population; McCarthy, Population History. Duben estimates that reporting in Istanbul was less complete for the petit bourgeois, artisanal and working classes. Alan Duben, "Household Formation in Late Ottoman Istanbul," International Journal of Middle East Studies 22, no. 4 (1990). Mutlu discusses the issue of Armenian undercounting in certain provinces. Mutlu, "Late Ottoman Population and Its Ethnic Distribution." In a later work McCarthy argued that undercounting in Jerusalem due to age and sex was 7.5 percent, the lowest in all the Arab provinces. McCarthy, Population History, 193.

13 Stanford Shaw, "The Population of Istanbul in the 19th Century," International Journal of Middle East Studies 10, no. 2 (1979). Duben and Behar's monumental work was based on a 5 percent sampling of five central neighborhoods in Istanbul with Muslim populations only. Alan Duben, "Household Formation"; Cem Behar and Alan Duben, Istanbul Households: Marriage, Family, and Fertility, 1880-1940 (Cambridge: Cambridge University Press, 1991). In 2014 Duben and Behar's samples were uploaded to the Mosaic Census project on European demographic history, and are currently available for scholars to download: http://www.censusmosaic.org/data/mosaic-data-files. In addition, the original defter pages, transcription sheets, methodological notes, and related documents have been uploaded to SALT Istanbul's website and are accessible for comparison: "Istanbul 
of local demographic history and historical geography. Alexander Schölch's pioneering work linked the demographic, economic and political history of Palestine based on earlier censuses and diplomatic records. ${ }^{14}$ Adar Arnon has been the only scholar to publish on the 1299 Jerusalem census, which he did from a more geographic perspective. ${ }^{15}$

The most comprehensive research utilizing the Palestinian census materials, this time on the 1321 census, was carried out by the late Uziel Schmelz, a demographer aided by a research team of transcribers and computer specialists. His research is based on more rigorous demographic method and makes arguments about aggregate and average population characteristics. ${ }^{16}$ Among the more suggestive revelations of Schmelz's work was that many Jerusalem neighborhoods were mixed and heterogeneous, rather than ethno-religiously homogeneous, as had been assumed by much of the scholarship on Jerusalem until that point. However, certain issues elude us even at the city level and

Households," Salt Research, accessed January 16, 2018, https://www.archives.saltresearch .org/R/1 ${ }_{93}$ PGILMGKFP6XLXVB4FAIML5XK4KGBLYKFH7 ${ }_{7}$ LLHCPY188JH-o1210?func= collections\&collection_id $=3241$.

14 Schölch, "The Demographic Development of Palestine."

15 Adar Arnon, "Mifkede ha-'Ukhlusiya bi-Rushalayim bi-Shalhe ha-Tekufa ha-'Otomanit" [Censuses of the population in Jerusalem at the end of the Ottoman period], Cathedra, no. 6 (1977); Arnon, "The Quarters of Jerusalem in the Ottoman Period," Middle Eastern Studies 28, no. 1 (1992). Although the historicized discussion of quarter names and boundaries is of value, Arnon makes geographic mistakes about certain places. For a back and forth discussion on some of these points, see Menachem Levin, "Be'ayot Zihuyan shel Shekhunot Yerushalayim lefi Sheman ha-'Aravi-ha-'Otomani be-Sifre ha-Nufus" [Problems of identification of Jerusalem neighborhoods according to their Arabic-Ottoman names in the census books], Cathedra, no. 15 (1980); Adar Arnon, "Teguva le-He'arot M. Levin 'al Zihuy Shemot Rov'e Yerushalayim ba-Tekufa ha-'Otomanit" [Response to the comments of M. Levin on the identification of the names of Jerusalem quarters in the Ottoman period], Cathedra, no. 15 (1980). In addition, Arnon's numbers seem to be drawn simply from the total counts offered in the archive table of contents for each defter, and represent a significant undercount in some areas.

16 Uziel O. Schmelz, "Population Characteristics of Jerusalem and Hebron Regions According to Ottoman Census of 1905," in Ottoman Palestine, 1800-1914: Studies in Economic and Social History, ed. Gad Gilbar (Leiden: Brill, 199o); Uziel O. Schmelz, "Ha-'Ukhlusiya haKelalit be-'Erets Yisrảel: Godel ha-'Ukhlusiya ha-Kelalit ba-'Arets 'Erev ha-Milhama” [The general population in the land of Israel: the size of the general population in the country on the eve of the war], in Be-Matsor u-Vematsok: -'Erets Yisrảel be-Milhemet ha'Olam ha-Rishona [Siege and distress: the land of Israel during the First World War], ed. Mordechai Eliav (Jerusalem: Yad Ben Zvi, 1991); Schmelz, "The Population of Jerusalem's Urban Neighborhoods according to the Ottoman Census of 1905," Scripta Hierosolymitana 35 (1994). However, Schmelz's data, too, shows some incompatibility with mahalle-level studies by Büssow and myself. 
necessitate a closer look at the household, neighborhood, and millet levels. For example, questions such as urban segregation look very different once we scale down within the city. Focusing on the neighborhood level can reveal smallerscale patterns of integration or segregation and can also reveal other neighborhood characteristics. ${ }^{17}$

While Schölch's, Arnon's, and Schmelz's works were important contributions to the demographic history of southern Palestine, for social historians, aggregate city-, province-, or empire-wide studies of the nüfüs are of limited value on their own and require a careful incorporation of qualitative sources and questions. Duben and Behar's work on Istanbul provided one model for how this could be done; they brought extensive court records, newspaper accounts, autobiographies, oral, and other primary sources to give broader social context to their quantitative data on household formation and family life. In a second related study, Behar later fleshed out the neighborhood of the census samples, Kasap İlyas, on a broader social and economic basis. ${ }^{18}$ Likewise, although on a much smaller scale, Johann Büssow studied samples of several Jerusalem neighborhoods in order to provide broader context for the biographies and historical trends discussed in his larger work. ${ }^{19}$ More localized and multimethodological works along these lines will add to the value of census records as a historical source.

Very recently, a third approach to the nüfüs has focused on aspects of governmentality and intercommunal politics rather than on the empirical data it collected. The most outstanding example of this kind of approach to the census has been the work of İpek Yosmaoğlu, who examined the contested ethno-national-religious categories and categorization surrounding the 1321 census in the Balkans. ${ }^{20}$ Yosmaoğlu's work turns our attention to the ways in which the census categories themselves were constructed, debated and challenged, as well as to how population figured into nationalist and international struggles in the late Ottoman period. This is a valuable contribution to better understanding Ottoman governmentality and state-society relations in the various corners of the empire.

17 See my forthcoming article "Mapping Urban Communities in Late Ottoman Jerusalem: A Digital Neighborhood Study."

18 Cem Behar, A Neighborhood in Ottoman Istanbul: Fruit Vendors and Civil Servants in the Kasap Ilyas Mahalle (Albany: State University of New York Press, 2003).

19 Büssow, Hamidian Palestine, 140-65.

20 İpek K. Yosmaoğlu, "Counting Bodies, Shaping Souls: The 1903 Census and National Identity in Ottoman Macedonia," International Journal of Middle East Studies 38, no. 1 (2006). 


\section{Reading the Jerusalem Census Despite Lacks and Gaps}

Given this snapshot of the changing Ottoman census system as well as its historiography, it is now time to turn to look at the census in Jerusalem. In my view, a return to the primary source itself opens the doors for a more finegrained analysis of both microhistorical and macrohistorical questions.

Over $45^{\circ}$ original notebooks of the Palestine census (nüfüs defterleri) from three periods are housed in the Israel State Archives (ISA): the 1299 census (1880s), the 1321 census (early 190os), and a third update to the census in 1914${ }_{15}$, apparently conducted in Jerusalem only among newly Ottomanized Jews. ${ }^{21}$ An important book published by Yonatan Pagis in 1997 to aid the use of the nüfüs records includes a brief historical introduction to the nüfüs based on English and Hebrew secondary sources as well as some details about the nüfüs collection, including methodological matters and detailed descriptions of the categories of records. The notebooks are of various types of official census registrations: 147 draft registers (mesvedde defterleri) and 231 basic registers (esās defterleri), an additional 10 "foreign registers" (including nonlocal Ottoman officials as well as foreign residents), 47 life cycle events registers (vukúät defterleri - which includes birth, death, marriage, and divorce registers), and 17 army registers. In addition, there are eight mukhtar notebooks from the Ashkenazi Jewish populations in Jerusalem, as well as one mukhtar notebook from the Muslim population near al-Majdal 'Asqalan (today's Ashkelon). ${ }^{22}$

The bulk of Pagis' book is made up of an index categorized by location. Although not immediately apparent due to the format of the index, it turns out that the first sixty-five notebooks (defters) deal with the city of Jerusalem and include draft and basic notebooks from the three census periods. Another large percentage of notebooks deals with 130 villages, towns, encampments, and colonies in the districts surrounding Jerusalem; these villages to the west and south of Jerusalem were forcibly depopulated during and after

21 Pagis tells a very partial history of the notebooks; he writes that no books from Tulkaram or Jenin districts have been located. In addition, the records for the north of Palestine are spotty, given that those districts were in the vilayet of Beirut in the Ottoman period, and apparently not all of the administrative records were transferred between the French and British mandatory authorities. Yonatan Pagis, Mifkede ha-'Ukhlusin ha-'Otomaniyim be-'Erets Yisrảel 1875-1918 [Ottoman population censuses in the land of Israel, 1875-1918] (Jerusalem: Achva Press, 1997), 29-32.

22 Ibid., 19-25. Both Pagis and Karpat mention "summary registers" (icmäl defterleri) as having been compiled by census officials, but they do not appear to have survived for the Jerusalem district. 
the 1948 war, whereas many of the villages to the north and east of Jerusalem, which were under Jordanian control until the 1967 war, have been incorporated into Jerusalem's contemporary municipal boundaries since then. In an appendix at the back of the book, Pagis includes a neighborhood-level listing of the Jerusalem census records, including helpful (though not comprehensive) information on neighborhood boundaries and landmarks. In addition, there are eight separate life cycle defters from Jerusalem between 1905 and 1917, including birth, death, marriage, and divorce registers. Unfortunately, none of the extant army registers are from Jerusalem.

Until the last archival reorganization of winter $2015^{-16}$, when the reading room of the ISA was declared permanently closed, microfilm copies of the nüfüs defterleri were available for public viewing. ${ }^{23}$ As of late 2017, digitized copies of the microfilms have been made available on the archive's website. In addition, all eighty-three microfilms of the entire Ottoman Palestine census were purchased by the Church of Jesus Christ of Latter-Day Saints decades ago, and are available through their regional Family History Centers for on-site consultation. ${ }^{24}$

As it turns out, though, accessing the census records is the rather straightforward part of the process. Putting them to use is significantly more complicated. First, neither the Pagis book nor the archive catalog provides a simple listing of each defter and its contents. Even more problematic is that the desired defter must be matched with the correct microfilm reel by referencing a paper folder available only in the reading room. This step is necessary in order to make use of the LDS microfilms as well. Furthermore, the Pagis index is organized rather

23 For the archive's account of its transition to digital format, see "A New Website with Free Birth-pangs," Israel's Documented Story, April 12, 2016, accessed January 16, 2018, http:// israelsdocuments.blogspot.co.il/2016/04/a-new-website-with-free-birth-pangs.html. The Middle East Studies Association (MESA), the Association for Civil Rights in Israel (ACRI), and numerous Israeli and foreign scholars have protested the decision to close the reading room and render actual documents off-limits. For more on this, see "Israel State Archives End Access to Paper Records; Archive Users Protest the Move," Akevot Institute for Israeli-Palestinian Conflict Research, n.d., accessed January 16, 2018, http:// akevot.org.il/en/news-item/state-archive-ends-access-to-paper. For a discussion of some of the implications for research, see "Past as Probate: An Interview With Historians About Israel's Archives," The Nakba Files, June 6, 2016, http://nakbafiles.org/2016/o6/o6/ past-as-probate-an-interview-with-historians-about-israels-archives, and "Archives Week on The Nakba Files," The Nakba Files, May 26, 2016, http://nakbafiles.org/2016/05/26/ archives-week-on-the-nakba-files.

24 The Family History Centers, however, are staffed by church volunteers, and typically have very limited hours and older microfilm reader technology. 
haphazardly within each geographic location. This becomes particularly difficult for large cities such as Jerusalem, which contain dozens of original defters. In the end, I simply created an Excel spreadsheet to keep track of and rearrange the information on the microfilms and defters.

After doing this, it became apparent that the Pagis index contains some errors and omissions in the neighborhood-level appendix; more importantly, both it and the census archive itself are structured in a way that obscures a "connected" vision of Jerusalem's population. In other words, because the defters are grouped together by millet rather than by census year or neighborhood, in order to get even a neighborhood snapshot during one census, for example, one must consult up to eight separate defters for a comprehensive population account.

A second difficulty with the census records is the actual legibility of the records. Some of the microfilm copies are dark, blurry, and scratched, and parts of them are difficult to read; in these cases, not having access to the original notebooks is an additional problem. The census records were written in what might be considered a sliding scale of Ottoman Turkish to Ottomanized Arabic, depending on the scribe. Some scribes used exclusively Turkish words and terminology, whereas others used Arabic, and others used a mixture. Some crafts and trades were labeled with different terms, and it is reasonable to wonder whether we can assume a total equivalence between the Turkish and Arabic terms, or whether there might have been meaningful or even subtle distinctions between the two. The dual language issue also presents a minor problem when encountering scribal errors in language or transcription where it is unclear what the intended word was. However, it can be a more significant problem to understand some of the transcriptions of non-Arabic names, which were transliterated into Arabic letters in an inconsistent or incorrect manner.

A third difficulty of the materials is the inconsistency of the submitted information, which makes quantitative aggregates and geospatial uses of the census somewhat-to-quite problematic. First, there is a high percentage of gaps in several specific data fields: occupation, languages known (while not a separate data field, this was occasionally included under occupation), but also most of the data on the second page of the census form. In the case of occupations, not infrequently the item is left blank; at other times "bilā șan'at" (without a trade) is explicitly written. Is there a substantive difference between the social and economic status of the two manners of entry or lack of entry, or are these simply the vagaries of reporting or recording? Similarly, when they are listed, languages are distinguished by reading, writing, and spoken knowledge; how accurate can we assume this information was at least among those 
who offered the data? Alternatively, drawing on evidence from biographical records that reveals the inconsistent reporting of language skills in the census, why might they have concealed or failed to mention their language abilities?

More serious for spatial purposes is the absence of locational information in large numbers of records - for all non-Muslims in the 1299 census, and for variable percentages of households in the 1321 census. In the 1321 census, some households have explicit locational information, including street, building number, and apartment number, while others have no identifying information other than neighborhood; the degree of completeness varies by neighborhood, millet, and class. In one neighborhood, al-Wad, the locational data in the 1321 census varies wildly by millet: 22 percent of Muslims and Greek Orthodox Christians do not have any locational data, but fully 49 percent of Maghrebi Jews and $5^{2}$ percent of Sephardi Jews have none. ${ }^{25}$ This means that while many households can be located quite specifically in the urban landscape, others can only be located more loosely within a neighborhood, a shortcoming which affects our understanding of the urban topography significantly.

Related to this, the census records provide no information about the census tracts, the geographic boundaries of mahalle and zuka $a$, or the numbering system used for houses. Unfortunately, there is no map, table, or descriptive information to accompany the notebooks. Together this poses a direct problem when one tries to utilize Gis to map out the census, a problem I write about elsewhere. ${ }^{26}$ It is certainly possible to gather some of this geographic and locational information through other means, as I am attempting to do, but it is necessarily laborious and incomplete. The importance of these methodological issues will vary according to the kind of study being conducted; for some studies, conceivably, space will not matter at all.

At the same time, it is worth remembering that the kind of geographic data necessary for plotting a household on GIS might be very far from the historical understanding of that space itself. Street names, for example, had several variants, and street segments were often conceptualized and referred to by a landmark rather than in continuous linear terms. Furthermore, while we know that house numbers existed starting already in the mid-nineteenth century in Jerusalem, when the Ottoman governor required their issuance, ${ }^{27}$ these numbers were not used on a daily basis. Instead, popular and legal geographic

25 Data taken from my research.

26 See Campos, "Mapping Urban Communities in Late Ottoman Jerusalem."

27 On this see Wallach, "Readings in Conflict," 140. 
markers were related to property description, ownership, rentership and adjacency to other properties. ${ }^{28}$

\section{Conclusion: To be Continued}

Despite its limitations and challenges, at its best, there is no question that the census can flesh out our understanding of Jerusalemite households in an intimate way. More so than in any other existing source, we meet families, learn about the professional profile of government clerks, bakers, shoemakers, teachers, greengrocers and businessmen, learn the names of wives and daughters and mothers and sisters. We also get a fascinating portrait of rural, regional, and international migration to Jerusalem. We are alerted to the presence of groups in the city who have eluded historical study - African migrants, heterodox Muslim gypsy sects, Protestant converts, and many kinds of "marginal" women (concubines, servants, those who married out of their religious communities, those forced to head up a household on their own due to widowhood or divorce).

We can also begin to illustrate the urban landscape with people in their homes and shops and markets, side by side with the more and less prominent religious institutions that have dotted the Jerusalem landscape. Combining the two censuses, we can track the changing urban landscape over a thirty-year period (between 1299 and 1321) as families moved from intra to extra muros neighborhoods, as households began to shrink and reconstitute themselves, as sons received modern educations or took apprenticeships that paved paths for them different from those of their fathers. We can carefully construct kinship ties within the city, tracing the strategies behind marriages.

Beyond this critical "thickening" of Jerusalem from the bottom up, the real promise of the census perhaps lies in its power as a database to be used in conjunction with other primary sources. Family archives, newspaper reports, court records and contracts, and myriad other primary sources can shed further light on the life cycles of ordinary and elite Jerusalemites alike. Furthermore, in the age of the digital humanities, a digitized, mapped and linked Ottoman census could provide us with a rich visual and textual record of Jerusalem and Jerusalemites in its earlier, truly connected moments. ${ }^{29}$

28 See some of the legal descriptions of properties in Eliezer Rivlin, "Hazakot shel Hatserot u-Vatim bi-Rushalayim" [Subleases of courtyards and houses in Jerusalem], in Festschrift Dr. Jakob Freiman zum 70 Geburtstag (Berlin: Viktoria, 1937).

29 This kind of project is the subject of my current grant proposal under consideration, "Jerusalem 1905." 